\title{
Towards Global Knowledge Society: A SWOT Analysis of Higher Education of Pakistan in Context of Internationalization
}

\author{
Jamshed Khalida ${ }^{*}$, Anees Janee Alia, Mohammad Khaleela, Md. Shamimul Islama, Qi Fung Shu ${ }^{a}$ \\ a School of Management, University Sains Malaysia \\ ${ }^{*}$ Corresponding author's email address: jamshed.jt@gmail.com
}

\section{A R T I C L E I N F O}

Received: 06-02-2017

Accepted: 24-02-2017

Available online: 28-02-2017

Keywords:

Internationalization;

Globalization;

Higher education;

Student mobility.

JEL Classification:

I23,I22, H52, H75

\begin{abstract}
A B S T R A C T
Purpose - The purpose of this study to overview the trends of higher education globally, within Asia Pacific Region and specially in Pakistan. Most importantly, current study highlights the strengths and opportunities as well as weakness and threads of Pakistan's higher education system by proposing a SWOT analysis of higher education internationalization. Design/methodology/approach - This exploratory research is meant to appear in conjunction with more discrete and in-depth previous literature regarding higher education internationalization. Findings - It is investigated that higher education institutions in Pakistan are in need to rethink and reshape internationalization policies and strategies following global standard which may lead them towards global knowledge society. Quality of higher education can be enhanced by developing internationalized curriculum, recruiting international students/staff and establishing international research collaboration programs. Originality/value - In the present study a SWOT analysis of internationalization has been proposed which illustrates the internal and external factors which are positively or negatively impacting the higher education system in Pakistan.
\end{abstract}

This is an open access article under the terms of the Creative Commons Attribution License 4.0, which allows use, distribution and reproduction in any medium, provided the original work is properly cited.

DOI: http://dx.doi.org/10.18533/job.v2i2.65

ISSN 2380-4041(Print), ISSN 2380-405X(Online)

\section{Introduction}

One major factor in the $21^{\text {st }}$ century is that the world entered a fast-tracked process of changes encompassing the fields of economy, science and technology, communications, education, culture, and politics. In education field, Internationalization is one of the most significant enticements to alter higher education system (Agrawal \& Tan, 2014; Byun \& Kim, 2011; Qureshi, Janjua, Zaman, Lodhi, \& Tariq, 2014). Internationalization of higher education has become popular since the early 1980s in education industry (Knight, 2014).

The approach to higher education internationalization has been associated with student and staff mobility, internationalized curriculum, international research collaboration programs, increasing establishment of international branch campuses. Knight (1994) explained the internationalization as 'the process of integrating an international, intercultural dimension into the teaching, research and service functions of the institution.' Knight also describes the concept of internationalization and globalization as 'internationalization is changing the world of higher education, and globalization is changing the world of internationalization' (Knight, 2006).

Internationalization of higher education demonstrated the concepts of networking, cultures, knowledge, and values. Consequently, internationalization has become an indicator of quality in HEIs (Urban \& Palmer, 2013). Nonetheless, the growing usage of internationalization in representing the international measure of higher 
education, there is also a great bewilderment about its implication (Guo \& Alfred, 2013; Knight, 2004). Internationalization of higher education consisted of two major dimensions i.e. internationalization at home and internationalization of cross-border education (Ashcroft, Abdullahi, Kajberg, \& Virkus, 2007). Internationalization at home is related to the intercultural and international dimension of learning at the home campus. On the other hand, as explained by Naidoo (2006), cross-border internationalization relates to activities in abroad for educational learning i.e. student/staff exchange, research collaboration programs, the opening of an overseas branch campus.

Universities in the $21^{\text {st }}$ century become more competitive because of modernization and globalization. Institutions are nowadays trying to recruit best students as well as staff and best research development strategies to compete in HE industry and get a long term reputation (Warwick, 2014). Pakistan is also in the struggle to develop its higher education system as per international standards. Without focusing internationalization and globalization in education, it is not possible to compete in the current global educational industry.

Given these conditions, it seems crucial to expose the issues facing by Pakistan on the way towards modernizing and internationalizing its higher education sector. Despite some studies has been carried out on internationalization of higher education in Pakistan, there is still excessive need to expose the strengths, weaknesses, opportunities and threats. The present study is an effort to fill this literature gap by exposing the current state of internationalization of higher education in Pakistan. Study emphasis on higher education trends towards internationalization globally, within Asia Pacific region and specifically in Pakistan. Pakistan is in urgent need to develop certain strategies with an aim to promote higher education in global context. The study, in the end, proposed a SWOT analysis of higher education in Pakistan in context of internationalization.

For the most part, the current study provides an exciting opportunity to advance the understanding of internationalization and its impact on higher education industry. The study aims to contribute to the growing area of research on internationalization by exploring the issues and challenges facing by developing countries in Asia pacific region i.e. Pakistan. There are several important streams where the current study is helpful to higher education leadership and policy makers as well by highlighting the current opportunities and threads.

The remaining part of the paper proceeds as follows: in the next session, the researchers review some literature pertaining the internationalization trends in global market, Asia pacific region and Pakistan. Then, the study proposed a SWOT analysis of Pakistan's higher education in context of internationalization. Finally, the paper ends with the practical suggestions and conclusion.

\section{Literature review}

\subsection{Global trends in internationalization of HEIs}

In the decade of 1990, the sharp increase had been seen in internationalization activities. Those activities comprised of mobility of students and scholars, international research collaborations on educational programs and establishment of overseas branch campuses (Wang, 2013). The major reason behind that change was the modification of higher education systems and their structures globally. Altbach and Knight (2007) defined the medieval European origins of universities as international institutions as they attract students from many countries. Moreover, most of the universities have started following internationalization strategies, e.g. increasing the number of international students, recruiting international scholars, establishing cross-border branch campuses and enhancing the research cooperation and collaborations programs to survive in the competitive global environment (Hou, 2011).

Collaboration and competition are significant strategies for internationalization. Universities and institutions are using different strategies and practices to improve internationalization of higher education. The most commonly used practices are; exchange programs with other countries, internships, permanent and visiting staff exchange programs, internationalization at home activities and foreign language educational programs.

One research conducted by Jiang and Carpenter (2013) in the UK aiming to discover challenging facing by an institution in implementing internationalization strategy. The research exposed issues such as resource allocation which refers to the financial and human resources to strategy. Another issue is communication which is a crucial issue at all university levels, and operational process which is one of the most critical issues of operational process within faculties. Another study among US community colleges, organized by Harder (2010), has clearly pointed out that the institutions' support is the most significant component of the internationalization process in community colleges. 
US and UK are the most attractive countries for international students. UNESCO Institute for Statistics (2014) expose the places around the world which attract the most overseas students to their universities. The top 20 countries with the number of international students explained in Table 1.

Table 1: Top 20 countries for international students

\begin{tabular}{lrr}
\hline & Destination Country & Total Number of Int. Students \\
\hline 1 & US & 740482 \\
2 & UK & 427686 \\
3 & France & 271399 \\
4 & Australia & 249588 \\
5 & Germany & 206986 \\
6 & Russia & 173627 \\
7 & Japan & 150617 \\
8 & Canada & 120960 \\
9 & China & 88979 \\
10 & Italy & 77732 \\
11 & South Africa & 70428 \\
12 & Malaysia & 63625 \\
13 & South Korea & 59472 \\
14 & Austria & 58056 \\
15 & Netherlands & 57509 \\
16 & Spain & 55759 \\
17 & Singapore & 54162 \\
18 & Egypt & 52959 \\
19 & Saudi Arabia & 49011 \\
20 & United Arab Emirates & 46566 \\
\hline
\end{tabular}

Source: UNESCO Institute for Statistics, July 2014

\section{Internationalization of higher education in Asia pacific region}

Higher education services have been expanding with the development of globalization and now becoming comprehensive, market-oriented and prevailing as an industry among developed countries as well as in the AsiaPacific region. Asian countries; i.e. Australia and Singapore are trying to establish an international network by developing international academic offices to attract students to study in their country of origin.

The last two decades have witnessed of increasing flow of internationalization activities among Asian countries. For instance, the government of Japan launched its Global 30 Scheme in 2009 with a motive to enhance the number of international student to 300,000 by 2020 (Rivers, 2010). Taiwan in 2011, also declared a bold plan to position the Taiwan as a 'Key Centre of Higher Education in Southeast Asia' through exporting higher education to other countries. Likewise, during the decade of 1990, Singapore and Malaysia focused on the transnational education and established an international environment in their universities to becoming 'education hubs' (Sidhu \& Kaur, 2011).

By the continuous struggle and strategic plans towards globalization and internationalization of higher education, it can be said that within the next two decades, Asian countries will be the most attractive destination for international students. As Onuf (2012) stated that 'Asian countries will dominate the global demand for international higher education for the next two decades.' Bohm, Davis, Meares, and Pearce (2002) foresee that the higher education demand will raise upto 7.2 million international students in 2025 from 1.8 million international students in 2000. By 2025, Asia will represent some $70 \%$ of the total globalized higher education demand, which indicate an increase of $27 \%$ from 2000 .

THE (2016) announced the 200 most international universities in the world. The international outlook indicator considers each institution's proportion of international students and staff and the proportion of research papers published with at least one co-author from overseas country. For this ranking, all the institutions that feature in the top 800 of the 2015-2016 overall ranking have been considered. The Middle Eastern Institution, Qatar University is at the top of list while UK has deepest reservoir of international universities, claiming 64 institutions in the top 200. In United Arab Emirates, American University of Sharjah has the largest proportion (82\%) of international students. The Contribution of Asian universities in top 20 most international universities is shown in table 2; 
Table 2. THE World Most International Universities Ranking 2016 - Asian's Universities Contribution in top 20

\begin{tabular}{|c|c|c|c|c|}
\hline Rank & Institution & Country & $\begin{array}{r}\text { International } \\
\text { outlook }\end{array}$ & Region \\
\hline 1 & Qatar University & Qatar & 99.9 & Middle East \\
\hline 3 & University of Hong Kong & Hong Kong & 99.5 & East Asia \\
\hline 6 & University of Macau & Macao & 98.4 & East Asia \\
\hline 9 & National University of Singapore & Singapore & 96.2 & Southeast Asia \\
\hline 12 & American University of Sharjah & United Arab Emirates & 95.6 & Middle East \\
\hline 15 & United Arab Emirates University & United Arab Emirates & 95.0 & Middle East \\
\hline 17 & Nanyang Technological University & Singapore & 94.6 & Southeast Asia \\
\hline
\end{tabular}

Source: www.timeshighereducation.com

The last decade witnessed that there has been $78 \%$ increase in the student mobility as the number of students enrolled in overseas universities (Choudaha, Chang, \& Kono, 2013) and institutions increased to 3.6 million in 2010 from 2 million in 2000. The contribution of South East Asian countries is $28 \%$ of international students. China, among them, provides the largest pool of international students i.e. 17\%, while universities of USA, UK, and Australia are the home of these students. Out of total enrollment of international students, $19 \%$ are enrolled in American universities, 11\% in UK universities, 8\% in Australian universities (UNESCO, 2013). With the increasing student mobility, research collaboration also increased among countries in Asia. For instance, China, in 2013, formed 71,003 documents with international collaborations, compared with India's 17,484, Pakistan's 4,278 and Bangladesh's 1,566.

The countries in South Asian region i.e. Pakistan, are also in the struggle to globalize higher education. Higher Education Commission in Pakistan is striving to develop strategic alliances and institutional networks with foreign countries i.e. The Knowledge Exchange Strategic Plan (KESP), International Research Support Initiative Program, etc.

\section{Internationalization of higher education in Pakistan}

Majority of the developing countries like Pakistan are suffering from a perilous situation in keeping up with international standards of global higher education (Zakaria, Janjua, \& Fida, 2016). However, Pakistan has adopted the internationalization policies for higher education quite liberally. At the time of Partition in 1947, there were more than two dozen colleges and technical institutions but only one university in the provincial capital of Punjab, the Punjab University, Lahore. Today, there are 177 public and private universities in Pakistan.

Through the efforts of Higher Education Commission (HEC), student mobility trend has increased in Pakistan at a fast pace. According to (UNESCO, 2012), outbound student mobility ratio is 2.6, and a total number of mobile students are 35,086 who went abroad for education purpose mainly to USA and UK and also to Australia, Germany, Malaysia, etc. A total of 4986 scholars, Under the HEC overseas scholarship scheme, has been sent abroad under several scholarships and funding programs for MS, Ph.D., or post-doctoral research. Majority of the students went overseas in the field of technology, engineering and bio sciences.

Moreover, HEC awarded 1569 overseas scholarships under the 'Faculty Development Program' and 178 researchers have completed their PhDs uder this program. Another program named as 'Development of HighLevel Manpower S\&T through Split Ph.D. Program' 86 scholars have been sent abroad under this scheme for split Ph.D. (UNESCO, 2012). Advanced countries are also providing scholarships to students from Pakistan. The world's largest Fulbright Scholarship Program each year provides several scholarships to Pakistani students to study in the US higer education istitutions. Likewise, a large number of students travelled to Australia for higher education under the Australia-Pakistan Scholarship Program.

According to the annual report of HEC (2012), under Foreign Faculty Hiring Programs, adopted by Pakistan, more than 300 experts and scientists have been hired from different top leading universities or institutions worldwide. The report also revealed that through another scheme named as 'Visiting Scholars Program', 61 experts around the world have come to Pakistan. These experts offered their services and conducted workshops and seminars to share their experience and knowledge by spending two to eight weeks at public sector universities / DAIs.

Table 3. Outbound students from Pakistan to overseas

\begin{tabular}{lr}
\hline Country & Number of Students \\
\hline United Kingdom & 9,754 \\
United States & 5,176 \\
Australia & 3,078 \\
\hline
\end{tabular}




\begin{tabular}{lr}
\hline Sweden & 3,044 \\
Canada & 1,560 \\
Germany & 1,406 \\
Malaysia & 1,367 \\
Cyprus & 1,215 \\
Cuba & 934 \\
Kyrgyzstan & 911 \\
Saudi Arabia & 766 \\
France & 673 \\
Finland & 420 \\
Norway & 291 \\
Other Countries & 4,491 \\
Total Number of Mobile Students abroad & 35,086 \\
Outbound mobility ratio & 2.6 \\
Gross outbound enrolment ratio & 0.2 \\
\hline Sour
\end{tabular}

Source: UNESCO (2012)

However, the inbound mobility of international students towards Pakistan is not impressive. The International Islamic University (IIU) is at the top position in respect of international students' recruitment in Pakistan. There are 1726 international students belongs to 40 different countries. The National University of Science and Technology (NUST) has only 11 international students and in Bahria University there are only 14, while the COMSATS Institute of Information Technology (CIIT) Pakistan enrolled 21 International students during the year 2012-13 (Zakaria et al., 2016).

According to the report of HEC (2011), HEC processed 1225 cases of international students who applied for admission in Pakistan as mentioned in Table 4.

Table 4. Inbound mobility of international student in 2010 - 2011

\begin{tabular}{llr}
\hline Sr. & Country & No. of Int. Student Enrolled \\
\hline 1 & Afghanistan & 440 \\
2 & China & 315 \\
3 & Somalia & 133 \\
4 & Turkey & 60 \\
5 & Saudi Arabia & 46 \\
6 & Others & 231 \\
\hline Total & & 1225 \\
\hline
\end{tabular}

Source: Higher Education Commission of Pakistan Report 2010-2011

Some of the Pakistani universities struggled for internationalization, as indicated by HEC (2012), by providing research and academic programs and also offering enhanced facilities to induct International Students i.e. International Islamic University (IIU) and COMSATS Institute of Information Technology (CIIT). Universities has accelerated their marketing strategies internationally and started mutual agreements for research collaboration, student/staff exchange programs, joint ventures schemes to appeal more international students in their systems despite various cultural diversification and less developed infrastructure.

However, there is still a need of greater efforts to understand the level and necessities of internationalization in HEIs and to improve the quality of higher education and develop the infrastructure of the universities in such a way that attract international students. Investment in internationalization can be advantageous in multiple ways i.e. generate more revenue, goodwill and reputation in the long run and a competitive edge in the global market (Khalid, Ali, Islam, Khaleel, \& Shu, 2017).

\section{SWOT Analysis of Internationalization of HE in Pakistan}

SWOT analysis is an effective way to understand the existing level of internationalization as well as a guide for further action steps for improvements. In the current study, SWOT analysis is used as a mechanism to evaluate the strengths and weaknesses of the organizations as well as the opportunities and threats (Stewart \& Richardson, 2000).

\section{$5.1 \quad$ SWOT analysis}


Table 5. SWOT Analysis of Internationalization of HEIS

\begin{tabular}{|c|c|c|}
\hline & Positive & Negative \\
\hline & $\begin{array}{l}\text { Strengths } \\
\text { - Internationally recognized academic } \\
\text { programs and professional courses } \\
\text { - } \quad \text { Ideal location and size and regional vicinity } \\
\text { - Increasing flow of publications and research } \\
\text { activities } \\
\text { - } \text { HEC accreditation policy and quality } \\
\text { assurance strategies } \\
\text { - International fully and partially funded } \\
\text { scholarships } \\
\text { Good reputation of Pakistan's medical and } \\
\text { engineering education globally } \\
\text { - Partnerships and strategic alliances with } \\
\text { developing countries } \\
\text { Government increasing efforts to assist } \\
\text { universities for the enhancement of higher } \\
\text { education }\end{array}$ & $\begin{array}{l}\text { Weaknesses } \\
\text { - Inadequate national and institutional policy } \\
\text { to internationalize HEIs } \\
\text { - Lack of appropriate budget for } \\
\text { internationalization } \\
\text { - Poor higher education system } \\
\text { - Weak Legal System } \\
\text { - Inappropriate funding } \\
\text { - Lake of faculty development } \\
\text { - Lack of equipment and facilities for advance } \\
\text { research } \\
\text { Lack of international staff and faculty } \\
\text { members } \\
\text { Experienced staff leaving for greener } \\
\text { pastures } \\
\text { Lack of facilities for student welfare, } \\
\text { counseling and career guidance }\end{array}$ \\
\hline & 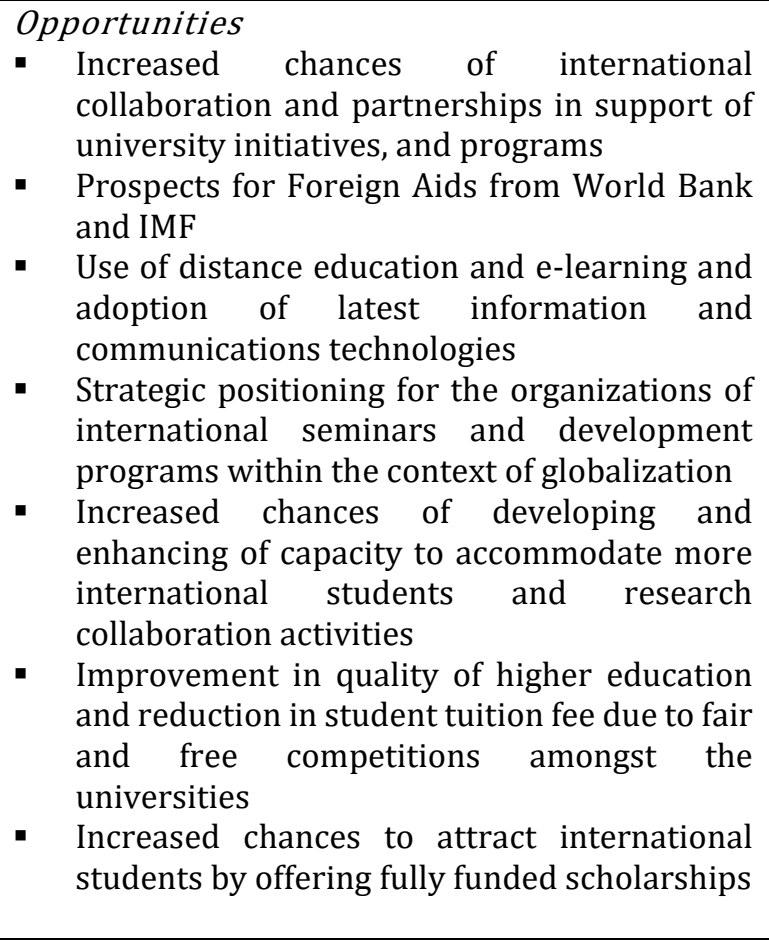 & $\begin{array}{l}\text { Threats } \\
\text { - Stakeholder resistance to develop an } \\
\text { international environment in HEIs } \\
\text { - Leadership deficit } \\
\text { - Fiscal uncertainty, mismanagement, and } \\
\text { corruption through misuse of power } \\
\text { - Underdeveloped research culture } \\
\text { - Inability of senior management in the } \\
\text { universities to hire and retain the } \\
\text { international students and faculty } \\
\text { - Limited resources for faculty and staff } \\
\text { development } \\
\text { - Growth of privatization of HEIs } \\
\text { - Politically represented academic and } \\
\text { decision-making bodies in universities } \\
\text { - Fear of terrorism } \\
\text { - Intellectual property rights, patent and } \\
\text { copyrights issues } \\
\text { Inappropriate distribution of national and } \\
\text { international funding } \\
\text { Less developed infrastructure of the } \\
\text { universities as compares to international } \\
\text { standards }\end{array}$ \\
\hline
\end{tabular}

\section{Practical suggestions}

On the way towards a global knowledge economy, internationalization is needed to emerge as one of the top priorities for institutes as well as for government. The study suggests some crucial recommendations to develop a strategic plan on institutional and national level. These recommendations based on the perspective of students, faculty, research, Curriculum, engagement and culture. The details have been mentioned below;

\begin{tabular}{ll}
\hline Indicators & Recommendations \\
\hline Student & Activities for 'Internationalization at Home' \\
& Announce international scholarships and fellowships schemes \\
& Expand and improve international student experience \\
& Promote distance learning / e-learning \\
Faculty & Recruit internationally experienced permanent and visiting faculty \\
& Develop faculty exchange programs with for foreign countries \\
& Buildup and amplify faculty members' skills and expertise in context of internationalization \\
& through global workshops and seminars \\
Research & International joint research collaboration and projects \\
\hline
\end{tabular}




\begin{tabular}{ll}
\hline & Equip universities with advanced technology and innovative instruments for scientific \\
& research \\
& Organize international conferences, seminars, and workshops \\
Curriculum & Start globally accredited degree programs \\
& Allow international joint degree programs \\
& Offer educational programs in foreign languages \\
Governance & Introduce national and institutional policy for internationalization \\
& Earmarked financial resources to promote and facilitate internationalization \\
& Establish international offices in universities \\
& Ensure effective accreditation and quality assurance policies \\
Engagement & Engage international alumni by developing a strong alumni network \\
& Enhance international strategic alliances, networks, and partnerships \\
Culture & Develop multicultural campus and build harmonization among universities \\
& Encourage the integration of international and domestic students / staff \\
\hline
\end{tabular}

\section{Conclusion}

The concept of globalization of higher education induce new challenges and, therefore, a universal skill set is required to overcome these challenges. Higher education in Pakistan is in need to find out parameters which would be useful for the smooth drive towards internationalization. Pakistan can enhance and improve the quality of higher education by developing internationalized curriculum, recruiting international students and staff, offering global scholarships and funding and establishing international research collaboration programs. Current study emphasis on recent trends and issues in global higher education to determine the roadmap through which internationalization of higher education could be possible. The study proposed SWOT analysis for the internationalization of higher education in Pakistan which illustrates the internal and external factors which are positively or negatively impacting the higher education system. Moreover, study suggests imperative recommendations and activities helpful to speed up the internationalization process. The study is useful for the higher education institutions to understand the fundamental needs of internationalization as well as it is useful for policy makers in developing long-term strategies. Future studies needed to implement the SWOT analysis among the universities in Pakistan to figure out the results.

\section{References}

Agrawal, A., \& Tan, V. M. (2014). Exploring determinants of students' experience, perceptions and loyalty intentions in higher education institutions. International Journal of Management in Education, 8(4), 343-361.

Altbach, P. G., \& Knight, J. (2007). The internationalization of higher education: Motivations and realities. Journal of Studies in International Education, 11(3-4), 290-305.

Ashcroft, L., Abdullahi, I., Kajberg, L., \& Virkus, S. (2007). Internationalization of LIS education in Europe and North America. New Library World, 108(1/2), 7-24.

Bohm, A., Davis, D., Meares, D., \& Pearce, D. (2002). Global student mobility 2025: Forecasts of the global demand for international higher education. IDP Education Australia.

Byun, K., \& Kim, M. (2011). Shifting patterns of the government's policies for the internationalization of Korean higher education. Journal of Studies in International Education, 15(5), 467-486.

Choudaha, R., Chang, L., \& Kono, Y. (2013). International student mobility trends 2013: Towards responsive recruitment strategies. World Education News \& Reviews, 26(2).

Guo, S., \& Alfred, M. V. (2013). Intensification of Faculty Engagement in the Internationalization of adult Education Critical Perspectives on International Education (pp. 135-148): Springer.

Harder, N. J. (2010). Internationalization efforts in United States community colleges: A comparative analysis of urban, suburban, and rural institutions. Community College Journal of Research and Practice, 35(1-2), 152164.

HEC. (2011). Annual Report Retrieved 6 Sep 2016, from www.hec.gov.pk

HEC. (2012). Annual Report. Retrieved 06 Sep, 2016, from www.hec.gov.pk

Hou, A. Y.-C. (2011). Quality assurance at a distance: international accreditation in Taiwan higher education. Higher Education, 61(2), 179-191.

Jiang, N., \& Carpenter, V. (2013). A case study of issues of strategy implementation in internationalization of higher education. International Journal of Educational Management, 27(1), 4-18.

Khalid, J., Ali, A. J., Islam, M. S., Khaleel, M., \& Shu, Q. F. (2017). Internationalization as Investment for Higher Education Institutions: Introducing a Framework to Enhance Investment in Internalization Practices. Review of Social Sciences, 2(2), 01-11.

Knight, J. (1994). Internationalization: Elements and Checkpoints. CBIE Research No. 7: ERIC. 
Knight, J. (2004). Internationalization remodeled: Definition, approaches, and rationales. Journal of Studies in International Education, 8(1), 5-31.

Knight, J. (2006). Crossborder education: An analytical framework for program and provider mobility HIGHER EDUCATION: (pp. 345-395): Springer.

Knight, J. (2014). Is internationalisation of higher education having an identity crisis? The forefront of international higher education (pp. 75-87): Springer.

Naidoo, V. (2006). International education A tertiary-level industry update. Journal of Research in International Education, 5(3), 323-345.

Onuf, N. G. (2012). World of our making: rules and rule in social theory and international relations: Routledge.

Qureshi, M. I., Janjua, S. Y., Zaman, K., Lodhi, M. S., \& Tariq, Y. B. (2014). Internationalization of higher education institutions: implementation of DMAIC cycle. Scientometrics, 98(3), 2295-2310.

Rivers, D. J. (2010). Ideologies of internationalisation and the treatment of diversity within Japanese higher education. Journal of Higher Education Policy and Management, 32(5), 441-454.

Sidhu, G. K., \& Kaur, S. (2011). Enhancing global competence in higher education: Malaysia's strategic initiatives Higher education in the Asia-Pacific (pp. 219-236): Springer.

Stewart, S., \& Richardson, B. (2000). Reflection and its place in the curriculum on an undergraduate course: should it be assessed? Assessment \& Evaluation in Higher Education, 25(4), 369-380.

THE. (2016). The world's most international universities 2016. Retrieved 10 Sep 2016, 2016, from https://www.timeshighereducation.com/features/200-most-international-universities-world-2016

UNESCO. (2012). Annual Report. Retrieved 5 Sep, 2016, from http://www.unesco.org/new/en/education/resources/online-materials/publications/

UNESCO. (2013). UNESCO Annual report. $\quad$ Retrieved 5 Sep, 2016, from http://www.unesco.org/new/en/education/resources/online-materials/publications/

Urban, E. L., \& Palmer, L. B. (2013). International students as a resource for internationalization of higher education. Journal of Studies in International Education, 1028315313511642.

Wang, L. (2013). Going global: The changing strategy of internationalisation of education in China. Journal of Higher Education Policy and Management, 35(3), 305-315.

Warwick, P. (2014). The international business of higher education-A managerial perspective on the internationalisation of UK universities. The International Journal of Management Education, 12(2), 91-103.

Zakaria, M., Janjua, S. Y., \& Fida, B. A. (2016). Internationalization of Higher Education: Trends and Policies in Pakistan. Bulletin of Education \& Research, 38(1). 